\title{
Energy metabolism and fasting in male and female insectivorous bats Molossus molossus (Chiroptera: Molossidae)
}

\author{
Freitas, MB. ${ }^{\mathrm{a} *}$, Goulart, $L S .{ }^{\mathrm{a}}$, Barros, MS. ${ }^{\mathrm{a}}$, Morais, DB. ${ }^{\mathrm{b}}$, Amaral, TS. ${ }^{\mathrm{a}}$ and Matta, SLP. ${ }^{\mathrm{b}}$

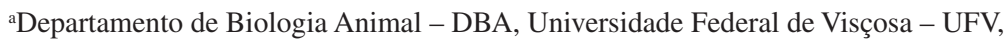 \\ Av. PH Rolfs, s/n, Campus UFV, CEP 36570-000, Viçosa, MG, Brazil \\ ${ }^{\text {b}}$ Departamento de Biologia Geral, Universidade Federal de Visçosa - UFV, \\ Av. PH Rolfs, s/n, Campus UFV, CEP 36570-000, Viçosa, MG, Brazil \\ *e-mail: mfreitas@ufv.br \\ Received April 24, 2009 - Accepted July 30, 2009 - Distributed August 31, 2010
}

(With 2 figures)

\begin{abstract}
Metabolic adaptations induced by 24 and 48 hours of fasting were investigated in male and female insectivorous bats (Molossus molossus Pallas, 1766). For this purpose, plasma glucose, non esterified fatty acids (NEFA), glycogen, protein and lipids concentrations in liver and muscles were obtained. Data presented here demonstrate that fed bats showed plasma glucose levels similar to those reported for other mammal species. In response to fasting, glycemia was decreased only in 48 hours fasted females. Plasma NEFA levels were similar in both sexes, and did not exhibit any changes during fasting. Considering the data from energy reserve variations, fed females presented an increased content of liver glycogen as well as higher breast muscle protein and limbs lipids concentrations, compared to fed males. In response to fasting, liver and muscle glycogen levels remained unchanged. Considering protein and lipid reserves, only females showed decreased values following fasting, as seen in breast, limbs and carcass lipids and breast muscle protein reserves, but still fail to keep glucose homeostasis after 48 hours without food. Taken together, our data suggest that the energy metabolism of insectivorous bats may vary according to sexual differences, a pattern that might be associated to different reproduction investments and costs between genders.
\end{abstract}

Keywords: plasma glucose, glycogen, insectivorous bats, metabolism, Molossus molossus.

\section{Metabolismo energético e resposta ao jejum em morcegos insetívoros Molossus molossus (Chirpotera: Molossidae)}

\section{Resumo}

As adaptações metabólicas induzidas pelo jejum foram investigadas em morcegos insetívoros machos e fêmeas (Molossus molossus Pallas, 1766) alimentados e submetidos ao jejum por 24 e 48 horas. Para este propósito, análises plasmáticas de glucose, ácidos graxos livres, glicogênio, proteína e lipídios do fígado e músculos foram analisados. Os dados obtidos demonstraram que o nível de glicose plasmática em morcegos alimentados foi similar ao apresentado por outras espécies de mamíferos. No entanto, em resposta ao jejum, a glicemia de fêmeas diminuiu significativamente após 48 horas, enquanto os níveis circulantes de machos permaneceram constantes. Os níveis de ácidos graxos não esterificados no plasma foram similares em ambos os sexos, e não houve mudança durante o jejum. Em relação às reservas energéticas, fêmeas alimentadas apresentaram maior teor de glicogênio no fígado, de proteína armazenada no músculo peitoral e lipídios nos músculos dos membros anteriores e posteriores, em comparação aos machos alimentados. Em resposta ao jejum, somente as fêmeas mostraram diminuição de algumas reservas energéticas, como a reserva lipídica dos músculos dos membros anteriores e posteriores, da carcaça e da reserva proteica do músculo peitoral. Apesar desta mobilização, as fêmeas, diferentemente dos machos, demonstraram uma incapacidade de manter a homeostase da glicose após 48 horas sem o alimento. Nossos dados sugerem que o metabolismo energético de morcegos insetívoros varia de acordo com o sexo, sendo que o padrão metabólico pode estar associado a diferenças de custo energético no investimento reprodutivo entre machos e fêmeas.

Palavras-chave: glicemia, glicogênio, morcegos insetívoros, metabolismo, Molossus molossus. 


\section{Introduction}

Bats (Order Chiroptera) are one of the most successful mammalian orders, and probably the most diverse. Among the suborder Microchiroptera, which has a virtually worldwide distribution, including tropical regions, species exhibit a large dietary diversity, being insectivorous, frugivorous, nectarivorous, carnivorous, omnivorous or sanguinivorous (Nowak, 1994).

It has long been reported that vertebrates consuming different types of diets diverge in the way they store body energy reserves and mobilise them during fasting. In this way, several studies have demonstrated that vertebrates consuming carbohydrate-rich diets, including fruit-eating bats, present increased liver glycogen levels and fat reserves when fed. Following short-term fasting, these animals show a decrease in plasma glucose, but the maintenance of glycemic homeostasis as fasting continues, mainly through liver glycogenolysis and gluconeogenesis (Kettelhut et al., 1980; Sartori et al., 1995; Brosnan, 1999; Turner et al., 1999; Tirone and Brunicardi, 2001; Pinheiro et al., 2006). However, an exception to this pattern has been reported for meadow voles (Microtus pennsylvanicus, Clethrionomys rutilus and Clethrionomys rufocanus). Those small rodents feed on carbohydrates but showed a severe hypoglycemia and liver glycogen depletion after 6 hours of fasting, causing early deaths in 1-2 days in the absence of food (Mosin, 1982, 1984; Nagy and Pistole, 1988), showing that particular characteristics of some species may originate some exceptions.

On the other hand, most studies with animals fed on protein-rich diets have demonstrated a different pattern. Plasma glucose do not decrease during fasting in these animals, in contrast to the severe fall observed in vertebrates fed on carbohydrate-rich diets, mainly due to continuous gluconeogenesis activation, which associates this particular diet to animals more resistant to fasting (Kettelhut et al., 1980; Veiga et al., 1982; Silva and Migliorini, 1990). Nevertheless, we have previously reported another exception to this pattern, the first involving a protein-rich diet animal: the common vampire bat (Desmodus rotundus). This unique mammal consumes his blood meal every night, but shows severe hypoglycemia when submitted to fasting, not being able to keep plasma glucose concentrations compatible to life for after only 12 hours of fasting, which characterises the species, unlike the others also fed on protein diets, as highly susceptible to fasting. This pattern seem to be shaped mainly due to its limited ability to store energy fuels when food is available and/or mobilise existing stores when food is scarce (Freitas et al., 2003, 2005, 2006).

As little is known about the metabolic adaptations to fasting in insectivorous bats, also fed on a protein-rich diet, and to investigate if there is another exception among bats, the aim of this study was to determine the typical metabolic patterns of fed insect eating bats (Molossus molossus) and their adaptations to 24 and 48 hours of fasting. For this purpose, plasma glucose, plasma non esterified fatty acids (NEFA), glycogen, protein and fat concentrations in the liver and muscle were determined in adult male and females bats.

\section{Material and Methods}

\subsection{Animals}

Adult male $(\mathrm{N}=34)$ and non-pregnant female $(\mathrm{N}=46)$ free-tailed bats (Molossus molossus), weighing 9-13 g, were captured from areas around Viçosa, MG, Brazil $\left(20^{\circ} 45^{\prime} \mathrm{S}\right.$ and $\left.42^{\circ} 52^{\prime} \mathrm{W}\right)$. Prior to the experiments, all bats were fed on Tenebrio young insects during two nights after capture. Food was offered at 10:00 PM, 00:00 and 07:00 AM. Water was available ad libitum. Fasting groups were then subjected to 24 and 48 hours of food deprivation, when only water was offered.

\subsection{Experimental procedures}

The bats were killed by decapitation and blood was directly collected from the trunk. Plasma glucose concentration was determined by the glucose-oxidase enzymatic method (Trinder, 1969; Barham and Trinder, 1972) (GLUCOX-500 - DOLES - Goiânia, GO, Brazil). Plasma NEFAs were determined using a NEFA $\mathrm{C}$ kit (WAKO - Richmond, VA - EUA). Liver and breast muscle glycogen concentrations were obtained from portions of these tissues, then placed in $2 \mathrm{~mL}$ of $\mathrm{KOH}$ (30\%), according to Sjörgren et al. (1938). Total protein concentrations from muscle (breast and limbs) and liver were obtained after homogenisation in a $0.9 \% \mathrm{NaCL}$ solution and determined with a protein assay kit (PIERCE - Rockford, IL - EUA). Portions of liver and muscles from breast and limbs were also homogenised in a chloroform-methanol (2:1) solution in accordance with Folch et al. (1957) for total lipid concentration, determined gravimetrically. Carcass fatty acids were established after removal of the aforementioned tissues and the digestive tract from its terminal esophagus section to the anus. Carcasses were completely digested in $100 \mathrm{~mL} \mathrm{KOH} \mathrm{(6} \mathrm{N),} \mathrm{filtered} \mathrm{and}$ added to the same volume of absolute alcohol, yielding a $\mathrm{KOH}$-ethanol (50\% v/v) solution. After extraction with chloroform, total fatty acid concentration of the carcasses was determined gravimetrically.

\subsection{Statistical analysis}

Data are presented as the mean \pm standard error of the mean (SEM). After being tested for normal distribution, comparisons between sex and fasting periods were carried out using one-way or two-way analysis of variance (ANOVA), followed by the Tukey test. Nonparametric Kruskal-Wallis method was also applied when data did not exhibit normal distribuitons. $\mathrm{p}<0.05$ was taken as the criterion of significance.

\section{Results}

\subsection{Plasma glucose and NEFA levels}

Plasma glucose levels of fed male and female bats were similar. In response to fasting, glycemia levels decreased only in females fasted for 48 hours $(F=5.44$; $\mathrm{p}=0.01)($ Figure 1$)$ 
Plasma NEFA concentration was similar in fed male and female bats, remaining unchanged after fasting in both sexes (Figure 2).

\subsection{Liver and muscle glycogen}

Liver glycogen concentration of fed females was significantly higher compared to males in the same condition. When submitted to fasting, the values remained unaltered for both males and females. The content of muscle glycogen in fed bats also remained similar to those found for fed animals (Table 1).

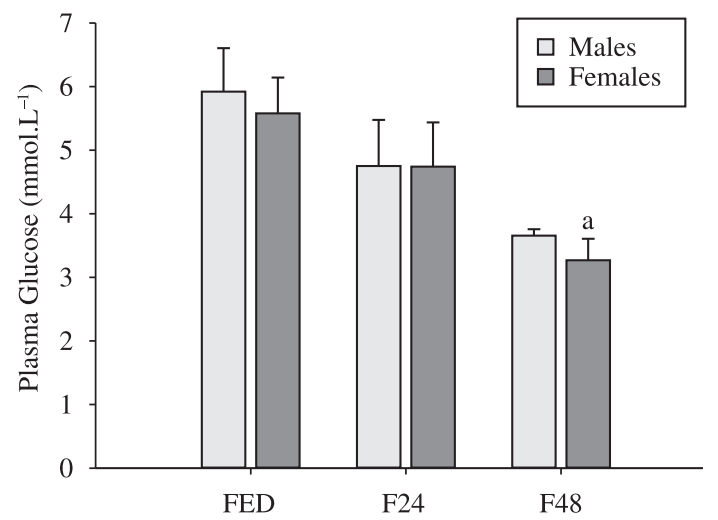

Figure 1. Changes in plasma glucose $\left(\mathrm{mmol}^{-1} \mathrm{~L}^{-1}\right)$ of fed (FED) and 24 e 48 hours fasted bats (F24, F48 respectively). Values represent the mean \pm SEM of 6-16 individuals per group. a $\mathrm{p}<0.05$ versus fed females.

\subsection{Liver and muscle lipids and carcass fatty acids}

Liver lipid concentrations in fed animals from both sexes were similar. In response to fasting, males submitted to 24 and 48 hours of fasting presented decreased concentrations of liver lipids $\left(\chi^{2}=10.17 ; p=0,01\right)$. Lipid concentrations on breast and limb muscles, as well as carcass fatty acids, were also similar on fed males and females, and in all cases, fasting induced decreased levels of those lipid stores only in 48-hours fasted females (breast: $\mathrm{F}=3.50$; $\mathrm{p}=0.03$; limbs: $\mathrm{F}=5.66 ; \mathrm{p}=0.01$; carcass: $\chi^{2}=6.92$; $\mathrm{p}=0.03)($ Table 1$)$.

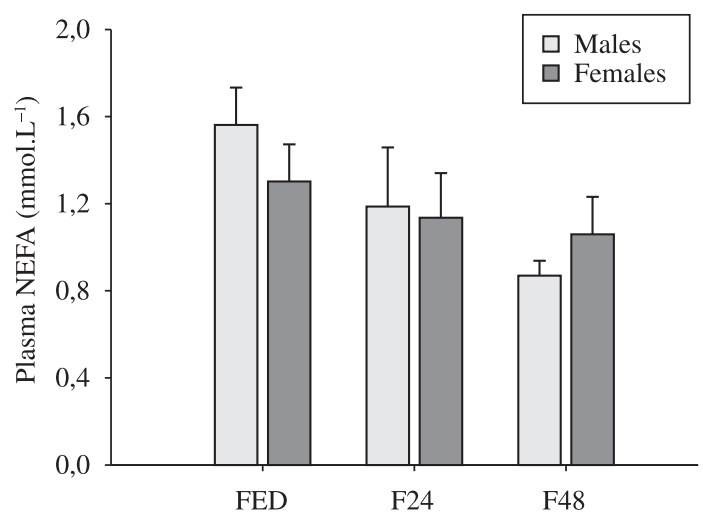

Figure 2. Changes in plasma non esterified fatty acids (NEFA; mmol.L ${ }^{-1}$ ) of fed (FED) and 24 e 48 hours fasted bats (F24, F48 respectively). Values represent the mean \pm SEM of 3-10 individuals per group.

Table 1. Liver and muscle glycogen, lipids and protein contents of fed, 24 and 48 hours fasted insectivorous bats.

\begin{tabular}{|c|c|c|c|c|c|c|}
\hline \multirow[t]{2}{*}{ Tissues } & \multicolumn{3}{|c|}{ Males } & \multicolumn{3}{|c|}{ Females } \\
\hline & FED & F24 & F48 & FED & F24 & F48 \\
\hline $\begin{array}{c}\text { Liver glycogen } \\
\left(\mu . \mathrm{mol}^{-1} \text { glucosil-units/g) }\right.\end{array}$ & $\begin{array}{c}47.30 \pm 14.75 \\
(13)\end{array}$ & $\begin{array}{c}32.33 \pm 11.70 \\
(8)\end{array}$ & $\begin{array}{c}27.56 \pm 17.60 \\
(5)\end{array}$ & $\begin{array}{c}113.63 \pm 20.32^{\#} \\
(16)\end{array}$ & $\begin{array}{c}72.91 \pm 12.31^{\#} \\
(14)\end{array}$ & $\begin{array}{c}52.62 \pm 9.56 \\
(9)\end{array}$ \\
\hline $\begin{array}{l}\text { Breast muscle glycogen } \\
\left(\mu . \mathrm{mol}^{-1} \text { glucosil-units } / \mathrm{g}\right)\end{array}$ & $\begin{array}{c}46.48 \pm 9.45 \\
(6)\end{array}$ & $\begin{array}{c}40.04 \pm 10.42 \\
(5)\end{array}$ & $\begin{array}{c}39.31 \pm 11.05 \\
(3)\end{array}$ & $\begin{array}{c}36.43 \pm 7.36 \\
(18)\end{array}$ & $\begin{array}{c}25.60 \pm 5.47 \\
(14)\end{array}$ & $\begin{array}{c}24.85 \pm 10.33 \\
(10)\end{array}$ \\
\hline $\begin{array}{l}\text { Liver protein } \\
\left(\mathrm{g} .100 \mathrm{~g}^{-1}\right)\end{array}$ & $\begin{array}{c}20.44 \pm 2.88 \\
(8)\end{array}$ & $\begin{array}{c}19.14 \pm 2.79 \\
(5)\end{array}$ & $\begin{array}{c}24.08 \pm 3.40 \\
(5)\end{array}$ & $\begin{array}{c}21.60 \pm 1.15 \\
(16)\end{array}$ & $\begin{array}{c}21.56 \pm 1.07 \\
(8)\end{array}$ & $\begin{array}{c}18.18 \pm 1.92 \\
(5)\end{array}$ \\
\hline $\begin{array}{l}\text { Breast muscle protein } \\
\qquad\left(\mathrm{g} .100 \mathrm{~g}^{-1}\right)\end{array}$ & $\begin{array}{l}8.9 \pm 0.61 \\
\quad(14)\end{array}$ & $\begin{array}{c}8.98 \pm 1.04 \\
(9)\end{array}$ & $\begin{array}{c}11.90 \pm 2.05 \\
(6)\end{array}$ & $\begin{array}{c}12.65 \pm 0.88^{\#} \\
(19)\end{array}$ & $\begin{array}{c}11.85 \pm 2.62 \\
(12)\end{array}$ & $\begin{array}{c}9.69 \pm 1.08 * \\
(12)\end{array}$ \\
\hline $\begin{array}{l}\text { Limb muscles protein } \\
\qquad\left(\mathrm{g} .100 \mathrm{~g} \mathrm{~g}^{-1}\right)\end{array}$ & $\begin{array}{c}15.68 \pm 1.28 \\
(11)\end{array}$ & $\begin{array}{c}14.18 \pm 1.67 \\
(5)\end{array}$ & $\begin{array}{c}13.58 \pm 1.90 \\
(5)\end{array}$ & $\begin{array}{c}20.16 \pm 1.90 \\
(12)\end{array}$ & $\begin{array}{c}16.35 \pm 1.60 \\
(8)\end{array}$ & $\begin{array}{c}13.61 \pm 1.60 \\
(4)\end{array}$ \\
\hline $\begin{array}{l}\text { Liver lipids } \\
\left(\mathrm{g} .100 \mathrm{~g} \mathrm{~g}^{-1}\right)\end{array}$ & $\begin{array}{c}8.20 \pm 1.14 \\
(5)\end{array}$ & $\begin{array}{c}5.25 \pm 0.68 * \\
(5)\end{array}$ & $\begin{array}{c}5.18^{*} \pm 0.01 \\
(5)\end{array}$ & $\begin{array}{c}7.25 \pm 0.68 \\
(11)\end{array}$ & $\begin{array}{c}5.82 \pm 0.51 \\
(11)\end{array}$ & $\begin{array}{c}7.21 \pm 1.01^{\#} \\
(8)\end{array}$ \\
\hline $\begin{array}{l}\text { Breast muscle lipids } \\
\quad\left(\mathrm{g} .100 \mathrm{~g}^{-1}\right)\end{array}$ & $\begin{array}{c}9.13 \pm 0.75 \\
(8)\end{array}$ & $\begin{array}{c}9.44 \pm 0.60 \\
(9)\end{array}$ & $\begin{array}{c}8.90 \pm 0.45 \\
(6)\end{array}$ & $\begin{array}{c}11.10 \pm 0.89 \\
(17)\end{array}$ & $\begin{array}{c}11.37 \pm 0.78 \\
(15)\end{array}$ & $\begin{array}{c}8.43 \pm 0.63 * \\
(12)\end{array}$ \\
\hline $\begin{array}{l}\text { Limb muscle lipids } \\
\qquad\left(\mathrm{g} .100 \mathrm{~g}^{-1}\right)\end{array}$ & $\begin{array}{c}3.82 \pm 0.96 \\
(8)\end{array}$ & $\begin{array}{c}7.14 \pm 1.07 \\
(7)\end{array}$ & $\begin{array}{c}3.78 \pm 0.18 \\
(2)\end{array}$ & $\begin{array}{c}9.91 \pm 1.29^{\#} \\
(11)\end{array}$ & $\begin{array}{c}5.66 \pm 0.68 \\
(11)\end{array}$ & $\begin{array}{c}5.80 \pm 0.97 \text { *\# } \\
(7)\end{array}$ \\
\hline $\begin{array}{l}\text { Carcass fatty acids } \\
\quad\left(\mathrm{g} .100 \mathrm{~g}^{-1}\right)\end{array}$ & $\begin{array}{c}6.8 \pm 0.483 \\
(10)\end{array}$ & $\begin{array}{c}6.16 \pm 1.05 \\
(7)\end{array}$ & $\begin{array}{c}4.43 \pm 0.35 \\
(6)\end{array}$ & $\begin{array}{c}8.72 \pm 0.65 \\
(16)\end{array}$ & $\begin{array}{c}8.30 \pm 1.74 \\
(14)\end{array}$ & $\begin{array}{c}5.84 \pm 0.78 * \\
(12)\end{array}$ \\
\hline
\end{tabular}

Data are mean \pm SEM; the number of bats is given in parentheses; * $p<0.05$ versus fed animal from the same sex; and ${ }^{\#} \mathrm{p}<0.05$ versus animals from the same nutritional condition, but different sex. 


\subsection{Muscle and liver protein}

Protein concentrations in breast muscle decreased significantly only in females after 48 hours without food $\left(\chi^{2}=6.92 ; p=0,03\right)$. Liver and limb muscle remained unaltered during fasting in male and female insectivorous bats (Table 1).

\section{Discussion}

Data from the present work indicates that male and female insectivorous bats presented an energy metabolism that significantly varied between sexes, particularly the adaptations to fasting, although, in general, the metabolic pattern of Molossus molossus resembles, in many aspects, the pattern exhibited by other vertebrates also fed high-protein (HP) diets.

Plasma glucose levels in both male and female fed bats, for instance, were similar to those reported for other bat species (Freitas et al., 2005; Pinheiro et al., 2006) or other mammals also fed with HP diets (Kettelhut et al., 1980; Opazo et al., 2004). Despite this similarity, Molossus molossus responses to fasting differed significantly between sexes. In males, the maintenance of plasma glucose levels during fasting indicate a better control of glucose homeostasis in the absence of food compared to females, whose levels were decreased after 48 hours of fasting. In fact, females seem to rely more on carbohydrate metabolism than males, despite both feed on a high protein diet (insects), since liver glycogen concentrations were higher in fed females compared to males. In response to fasting, no change in liver glycogen concentration was observed, although females demonstrated a clear tendency to lower values after 48 hours without food $\left(\chi^{2}=5.28 ; \mathrm{p}=0.07\right)$.

Studies with vertebrates fed on high-protein diets have demonstrated that these animals depend more on protein metabolism than on carbohydrate or lipid metabolism, including a reduced lipogenesis in protein fed animals (Botion et al., 1992).

In fed free-tailed bats, decreased lipid concentrations in both male and females in all tissues tested was also observed, compared to mammals fed on high-carbohydrate diets (Kettelhut et al., 1980; Pinheiro et al., 2006), similarly to those found in vampire bats, also fed with a HP diet (blood) (Freitas et al., 2003). However, in response to fasting, male and female insectivorous bats responded differently: females showed a consistent decrease in lipid concentration reserves in response to 48 hours fasting (breast and limbs muscle and carcass), while males did not show any change in response to fasting, except for liver lipids. Despite the fasting-induced decrease in lipid stores, females failed to increase plasma non esterified fatty acids in this period, which indicates that the observed mobilisation might not have been enough to raise NEFA levels maybe due to lower lipid reserves stored when food was available.

Similar to that observed for vampire bats (Freitas et al., 2003), protein concentration remained unchanged during fasting for both males and females, with the only exception for the decrease observed in the breast muscle in 48 hours fasted females.
Taken together, data presented here show that male and female insectivorous bats (Molossus molossus) present distinctive metabolic adaptations in response to fasting. In general, males were more resistant than females, being able to keep plasma glucose levels during food shortage (i.e. 24 and 48 hours fasting) and apparently mobilising fewer energy stores during this critical period. In contrast, females showed some fasting susceptibility, as they were not able to keep plasma glucose levels during fasting, which decreased after 48 hours to values near to those that severely pressure mammalian survival (Kraus-Friedmann, 1984). Notwithstanding the fasting susceptibility, females were more efficient in storing higher energy reserves when fed compared to males. These results indicate that the energy metabolism of insectivorous bats vary according to sexual differences. Other factors associated with energy metabolism, such as gender differences associated to reproduction investments, already reported for other females of insectivorous bat species (Widmaier et al., 1996; Srivastava and Krishna, 2008), may play a role in this distinctive pattern.

Acknowledgements - This work was supported by FAPEMIG (CBB 1905/06). We are also grateful to M. Cupertino, C. Pinto and G. del Giudice for field assistance; and Dr. M. Vilela for revising the English version. All animal captures were made with approval from the Brazilian Institute of Environment and Natural Resources (IBAMA - 1936505) and the State Institute of Forests (IEF - 121/06)

\section{References}

BARHAM, D. and TRINDER, P., 1972. An improved colour reagent for the determination of blood glucose by the oxidase system. Analyst, vol. 97, no. 151, p. 142-145.

BOTION, LM., KETTELHUT, IC. and MIGLIORINI, RH., 1992. Reduced lipogenesis in rats fed a high-protein, carbohydrate-free diet: participation of liver and four adipose depots. Brazilian Journal of. Medical and Biological Research, vol. 25, no. 4, p. $419-428$

BROSNAN, JT., 1999. Comments on metabolic needs for glucose and the role of gluconeogenesis. European Journal of Clinical Nutrition, vol. 53, no. 1, p. S107-S111.

FOLCH, J., LESS, M. and SLORNE-STANLEY, GH., 1957. A simple method for the isolation and purification of total lipids from animal tissues. Journal of Biological Chemistry, vol. 226, p. 497.

FREITAS, MB., PASSOS, CBC., VASCONCELOS, RB. and PINHEIRO, EC., 2005. Effects of short-term fasting on energy reserves of vampire bats. Comparative Biochemistry and Physiology, vol. 140B, no. 1, p. 59-62.

FREITAS, MB., WELKER, AF., MILLAN, SF. and PINHEIRO, EC., 2003. Metabolic responses induced by fasting in the common vampire bat Desmodus rotundus. Journal of Comparative Physiology, vol. 173B, no. 8, p. 703-707.

FREITAS, MB., WELKER, AF. and PINHEIRO, EC., 2006. Seasonal variation and food deprivation in common vampire bats (Chiroptera: Phyllostomidae). Brazilian Journal of Biology, vol. 66 , no. 4 , p. 1051-1055. 
KETTELHUT, IC., FOSS, MC. and MIGLIORINI, RH., 1980. Glucose homeostasis in a carnivorous animal (cat) and in rats fed a high protein diet. American Journal of Physiology, vol. 239, no. 5, p. R437- R444.

KRAUS-FRIEDMANN, N., 1984. Hormonal regulation of hepatic gluconeogenesis. Physiological Review, vol. 64, no. 3, p. $170-259$.

MOSIN, AF., 1982. Some physiological and biochemical features of starvation and reffeding in small wild rodents (Microtinae). Comparative Biochemistry and Physiology, vol. 71A, no. 1, p. 461-464.

MOSIN, AF., 1984. On the energy fuel in voles during their starvation. Comparative Biochemistry and Physiology, vol. 77A, no. 3, p. 563-565.

NAGY, TR. and PISTOLE, DH., 1988. The effects of fasting on some physiological parameters in the meadow vole Microtus pennylvanicus. Comparative Biochemistry and Physiology, vol. $91 \mathrm{~A}$, no. 4, p. 679-684.

NOWAK, RM., 1944. Walker's bats of the World. 5 ed. London: Johns Hopkins University Press. 204 p.

OPAZO, J., SOTO-GAMBOA, M. and BOZINOVIC, F., 2004. Blood glucose concentration in caviomorph rodents. Comparative Biochemistry and Physiology, vol. 137A, no. 1, p. 57-64.

PINHEIRO, EC., TADDEI, VA., MIGLIORINI, RH. and KETTELHUT, IC., 2006. Effect of fasting on carbohydrate metabolism in frugivorous bats (Artibeus lituratus and Artibeus jamaicensis). Comparative Biochemistry and Physiology, vol. 143B, no. 3, p. 279-284.

SARTORI, DR., MIGLIORINI, RH., VEIGA, JA., MOURA, JL. and KETTELHUT, IC., 1995. Metabolic adaptations induced by long-term fasting in quails. Comparative Biochemistry and Physiology, vol. 111A, no. 3, p. 487-493.
SILVA, SM. and MIGLIORINI, RH., 1990. Effects of starvation and refeeding on energy-linked metabolic process in the turtle (Phynops hilarii). Comparative Biochemistry and Physiology, vol. 96A, no. 3, p. 415-419.

SJÖRGREN, B., NOERDENSKJÖLD, T., HOLMGEENOL, H. and MÖLLERSTRÖM, J., 1938. Beitrag zur kenntnis der leberrhythmik (glycogen, phosphor und calcium in der kaninchenleber). European Journal of Physiology, vol. 240, p. 427-432.

SRIVASTAVA, RK. and KRISHNA, A., 2008. Seasonal adiposity, correlative changes in metabolic factors and unique reproductive activity in a vespertillionid bat, Scotophilus heathi. Journal of Experimental Zoology, vol. 309, no. 2, p. 94-110.

TIRONE, TA. and BRUNICARDI, FC., 2001. Overview of glucose regulation. World Journal of Surgery, vol. 25, no. 4, p. 461-467.

TRINDER, P., 1969. Determination of blood glucose using an oxidase-peroxidase system with a non-carcinogenic chromogen. Journal of Clinical Pathology, vol. 22, no. 2, p. 158-161.

TURNER, K., APPLEGATE, TJ. and LILBURN, MS., 1999. Effects of feeding high carbohydrate and fat diets. 1. growth and metabolic status of the posthatch poult following immediate or delayed access to feed. Poultry Science, vol. 78, p. 1573-1580.

VEIGA, JAS., ROSELINO, E., LINDER, C. and MIGLIORINI, RH., 1982. Effects of fasting and adrenalectomy on the kinetics of glucose metabolism in granivorous and carnivorous bird. Brazilian Journal of Medical and Biological Research, vol. 15, no. 2-3, p. 175-180.

WIDMAIER, EP., GORNSTEIN, ER., HENNESSEY, JL., BLOSS, JM., GREENBERG, JA. and KUNZ, TH., 1996. High plasma cholesterol, but low triglycerides and plaque-free arteries in Mexican free-tailed bats. American Journal of Physiology, vol. 271, no. 5, p. R1101-R1106. (part 2) 
